Institute of $\mathbf{F}_{\text {ood and }} \mathbf{A}$ gricultural $\mathbf{S}_{\text {ciences }}$

\title{
Energy from Crops: Production and Management of Biomass/Energy Crops on Phosphatic Clay in Central Florida1
}

\author{
J. A. Stricker, G. M. Prine, D. L. Anderson, D. B. Shibles, and T. C. Riddle ${ }^{2}$
}

\section{Introduction: Converting Biomass into Energy}

While it appears that biomass/energy crops may be successfully grown on phosphatic clay soils, a processing facility is needed to convert the biomass to energy in the form of methane, ethanol or electricity. Without an appropriate facility, there is no market for the crop. One strategy being explored is to co-fire biomass fuels with coal in existing power plants (Segrest, et al., 1998). Test burns with woody biomass have been successfully performed by Lakeland Electric at the McIntosh plant and by TECO at both the Gannon plant and the Polk Power Station. In addition, there are two ethanol plants near Bartow, one with 5 million gallons annual capacity, the second with 15 million gallons capacity. Both plants are presently idle but have the ability to convert sugars in sugarcane juice to ethanol, should market conditions permit. Both Lakeland Electric and TECO are exploring the possibility of generating electricity from renewable sources and selling it for a small premium as "green energy" (Stricker, et al., 1999).

Legislation currently pending in the U.S. Congress will require electric utilities to generate a small percent of electricity from renewable sources. Because of Florida's climate and geography, the only available renewable sources of electricity are from solar and biomass (Planet Power, 2003). In Florida, the estimated cost of generating electricity from solar photovoltaic modules is $\$ 0.18$ per $\mathrm{kWh}$, while the cost of electricity from biomass is in the range of $\$ 0.068$ to $\$ 0.08$ per kWh (Rahmani, et al., 2003).

Today, there is great concern about carbon dioxide $\left(\mathrm{CO}_{2}\right)$ buildup in the atmosphere related to global warming. Growing biomass crops and utilizing them as fuel to replace a portion of the coal used to generate electricity will reduce the amount of $\mathrm{CO}_{2}$ being released to the atmosphere. Burning coal releases carbon in the form $\mathrm{CO}_{2}$ that has been sequestered for millions of years, thus adding to $\mathrm{CO}_{2}$

1. This document is Circular 1084, a publication of the Agronomy Department, Florida Cooperative Extension Service, Institute of Food and Agricultural Sciences, University of Florida. Publication date: February 1993. Revised: September 2003. Visit the EDIS website at: http://edis.ifas.ufl.edu.

2. J.A. Stricker, county Extension director, Polk County, Bartow, FL 33830; G. M. Prine, professor, Agronomy Department, University of Florida, Gainesville, Fl 32611; D. L. Anderson, former associate professor, Everglades Research and Education Center, Belle Glade, FL 33430; D. B. Shibles, former manager, Mined Lands Agricultural Research/Demonstration Project, Bartow, FL 33830; T. C. Riddle, former biologist, MLAR/DP and University of Florida, Bartow FL 33830.

The use of trade names in this publication is solely for the purpose of providing specific information. UF/IFAS does not guarantee or warranty the products named, and references to them in this publication does not signify our approval to the exclusion of other products of suitable composition.

The Institute of Food and Agricultural Sciences is an equal opportunity/affirmative action employer authorized to provide research, educational information and other services only to individuals and institutions that function without regard to race, color, sex, age, handicap, or national origin. For information on obtaining other extension publications, contact your county Cooperative Extension Service office. Florida Cooperative Extension Service/Institute of Food and Agricultural Sciences/University of Florida/Christine Taylor Waddill, Dean. 
buildup. Biomass, on the other hand, during growth incorporates already existing $\mathrm{CO}_{2}$ and recycles it back to the atmosphere when it is burned (Cook and Beyea, 1996). Co-firing only $3 \%$ of biomass fuel at just one mid-sized coal power plant would reduce $\mathrm{CO}_{2}$ emissions equivalent to 41,000 large $(1 \mathrm{Kw})$ solar panels or taking 17,000 cars off the road (Planet Power, 2003).

Further $\mathrm{CO}_{2}$ reduction may be achieved by using municipal sludge (biosolids) or other organic sources of nitrogen in place of manufactured nitrogen fertilizer to grow biomass crops. Nitrogen fertilizer is manufactured from natural gas, and $\mathrm{CO}_{2}$ is released during the manufacturing process (Cook and Beyea, 1996).

\section{Growing Biomass/Energy Crops on Phosphatic Clay}

Biomass/energy crops have performed exceptionally well on phosphatic clay soil in central Florida. Total dry matter yield of selected sugarcane and elephantgrass varieties have averaged in the range of 20 to 25 tons (80 to 100 tons fresh weight) per acre per year over 4 years. Even higher yields have been observed with Erianthus. These yields were obtained with one harvest per year. Yield trends of some biomass selections included in one of two 4-year studies increased during the study while others declined. With one harvest per year, stand life for most of these crops will be 6 or more years. Biomass crops can be utilized in ethanol or methane production or by direct burning to produce electricity.

Phosphatic clay is a by-product of phosphate mining. Phosphate ore is a matrix of sand, clay, and phosphate minerals. Clay is washed from the ore matrix in the benefication process and pumped to large settling areas. After a settling area is filled, it is reclaimed by creating perimeter and lateral ditches to drain and allow the surface to dry. Additional drainage in the form of sloped beds is needed on flat, poorly drained settling areas. (See IFAS publication SS-MLR-01 Guidelines for Reclaiming Phosphatic Clay Settling Areas for Intensive Agriculture-available from the Cooperative Extension Office, PO Box 9005, Drawer HS03, Bartow, FL, 33831.) At the present time, there are 142,270 acres of phosphatic clay in Florida and this acreage will continue to increase as phosphate mining continues. The acreage of phosphatic clay that has been reclaimed is unknown at this time but has likely increased substantially from the 10,311 acres reported in 1991 (Source: personal communication, Florida Department of Environmental Protection (DEP), Bureau of Mine Reclamation, May 14, 2003).

Phosphatic clay as a man-made soil is unique in Florida, compared with natural soils that are typically sandy or organic in nature. Since most native Florida soils are infertile and have low water holding capacity, a considerable amount of energy in the form of fertilizers and irrigation are required to grow biomass crops successfully. In contrast, phosphatic clays have high fertility and water holding capacity, reducing the need for irrigation and fertilization other than nitrogen. No fertilization is needed for legume crops. Crop production on phosphatic clay soil requires low energy input which increases the incentive for biomass crop production.

\section{Soil Preparation}

The site selected to grow energy crops should have good surface drainage. The drainage system should remove all standing water within 24 hours of a heavy rain. Before planting time, at least 4 to 6 weeks should be allowed for soil preparation. Time is needed to kill weeds and grasses, if chemical control is used, or for clods to break down, if using mechanical control. Soil should be reasonably level and free of all weeds and grasses at planting. Mechanical cultivation, chemical cultivation, or a combination of both may be used.

Mechanical cultivation may consist of primary tillage with a moldboard plow followed by secondary tillage with a power tiller or disc harrow. Rain events occurring between tillage operations will help break up clods and hasten development of a firm, level seed bed. It may be necessary to spot treat bermudagrass with one or more applications of herbicide should it be present. Bermudagrass is not easily controlled with tillage alone. 
A seed bed may be prepared with one or two applications of a systemic herbicide such as glyphosate (Roundup ${ }^{\circledR}$ ) or fluazifop-butyl (Fusilade ${ }^{\circledR}$ ). A combination of herbicide and light disking is another way of preparing the soil for planting.

\section{Crop Selection}

Perennial crops that regenerate annually from buds at the base of the plant offer the greatest potential for energy-efficient production in central Florida. A number of these crops have been studied on phosphatic clay as a part of the research activities of the Mined Lands Agricultural Research/Demonstration Project. Crops include: elephantgrass (Pennisetum purpureum L.), energycane (Saccharum sp.), sugarcane (Saccharum sp.), Erianthus [Erianthus arundinaceum (Retz)], sweet sorghum [Sorghum bicolor (L.) Moench], forage sorghum [Sorghum bicolor (L.) Moench], and leucaena [Leucaena leucocephala (Lam.)] (Table 1).

Elephantgrass, energycane, sugarcane, and Erianthus are tall-growing, stiff-stemmed bunchgrasses. These plants have the ability to generate high leaf masses to totally intercept and utilize available sunlight in the later stages of the growing season. Erianthus tends to be more difficult to establish than elephantgrass or sugarcane. It also has a spreading growth habit which could create harvesting problems.

Sorghum is an annual tropical grass with large genetic variation. Sweet sorghum has been selected for its sugar content and is normally grown for molasses production. Forage sorghum has been selected for high yields of reasonably good quality animal feed. Sorghum varieties producing tall plants with large stems make the best candidates for biomass production. Both sweet and forage sorghum have a high potential for lodging. Lodging can result in harvest problems with ensuing loss of yield from both initial and ratoon crops.

Leucaena is a shrub-like tropical legume not requiring nitrogen fertilization. However, leucaena requires several years of growth before approaching maximum annual yield. The plant is woody and may have to be harvested with hand labor. Mechanical harvesting systems based on high capacity forage harvesters are being used on willow and poplar trees in Europe. These systems might be used on leucaena or other woody species in the U.S., but would require a large acreage to spread costs and management systems designed to accomodate mechanical harvesting.

\section{Planting}

Elephantgrass, energycane, sugarcane and Erianthus are all propagated from stem pieces. These perennial grasses may be planted either in late summer (weather permitting) or in the fall (Table 2). Summer planting should be completed no later than September 15th to avoid plant death due to freezing weather during the first winter. Summer planting has the advantage of producing a full harvest within 14 months. Disadvantages of summer planting include risk of having soil preparation and planting schedules disrupted by frequent rains; and, also, poor utilization of seed material because of immature growth. Seed material comes from a growing crop that will not mature until fall.

Fall and winter are the best times for planting perennial grasses. Planting can begin in early November and continue until a killing frost. Frost will destroy the planting material. Stem pieces planted in November and later will grow slowly with cool soil temperatures. Although a freeze may burn off leaves that have emerged, the growing point of the plant will remain below the soil surface. The young plants will survive and continue to grow.

Both sorghum and leucaena are propagated from seed. Sorghum may be planted from mid-March through early August. Sorghum planted in mid-March may be harvested two and possibly three times per year. Later plantings will only produce one or two harvests. In general, the later the planting the lower the yield potential.

Leucaena may be planted from April through July. Planting before the start of the rainy season may require supplemental irrigation for good plant emergence. Planting during the rainy season may result in difficulty in preparing a seed bed due to wet soil conditions. 
Row spacing is of concern especially for harvesting equipment. If forage harvesting equipment is to be used, row spacing should match that of the harvester, usually 38 to 48 inches. Machines, such as the Claas harvester used in Europe and equipped with a wood header, require a double-row system of two rows 30 inches apart separated by a 60 -inch middle (Deboys, 1995; Spinelli \& Kofman, 1996). If a cane harvester, similar to those used in south Florida, is used, row spacing of 60 inches will be required. Row spacing influences biomass composition. Generally, wide row spacing results in higher sugar content of tall grasses and canes with lower fiber content. However, narrower rows increase stand density which results in higher biomass yield, lower sugar, and greater fiber content.

For vegetatively propagated perennial grasses, furrows should be made with a plow or middle buster. Furrows should be 5 to 6 inches deep for sugarcane and 2 to 4 inches deep for elephantgrass. Canes should be cut so there are 2 or 3 nodes on each piece and placed in the furrow with two canes side by side. About 4 to 5 tons of canes will be needed to plant an acre.

Covering furrows can be difficult in phosphatic clay soil because clods may be formed during furrowing. A co-rotational power tiller (e. g., Lely Roterra or one made by Befco) has been used with good success when the tines are run at a depth of 2 to 3 inches. A peg- tooth harrow pulled at a $45^{\circ}$ angle to the furrows is also effective.

Sorghum and leucaena may be planted with a conventional plate-type corn planter. If a plate-type planter is used, it is necessary to find the correct size plates for the seed being planted. A plateless planter would be the easiest to use because the planter adjusts to different seed sizes without the need for plates. Ten pounds of seed per acre is recommended for both forage and sweet sorghum.

Leucaena seed is about the size of small watermelon seed. The seed should be scarified with acid, sodium hydroxide, or with boiling water to improve germination. It should also be inoculated with a specific rhizobium (e.g., Inoculum- $L$ marketed by the Nitragen Co., Inc., Brookfield, WI) and planted 24 to 36 inches apart in the row with $2-3$ seeds per drop. Finding adequate supplies of planting materials for large plantings of elephantgrass, energycane, Erianthus, and leucaena on short notice will be difficult. These crops are not grown in commercial quantities. It will be necessary to build up a stock of planting materials by planning ahead and establishing nurseries of species and varieties desired. For planning purposes, figure that one acre of perennial grass nursery will plant 10 to 15 acres (4 to 5 tons of canes planted per acre) 12 months from original planting, provided the nursery is well managed. Some commercial sugarcane varieties, such as CP72-1210 are grown in south Florida and planting material may be obtained from growers in that area. Leucaena seed is also not commercially available. A small amount of seed is available from people doing research with leucaena. Leucaena seed is presently harvested by hand. Sorghum seed, however, is readily available from commercial sources.

\section{Weed Control}

Once these biomass crops are established to a good stand they will be able to compete against weeds and grasses. However, weed control may be needed during the establishment phase. A pre-emergent herbicide may be used. Check the IFAS Weed Management Guide http://edis.ifas.ufl.edu/ TOPIC_GUIDE_Weed_Management_Guide for the latest recommendations on herbicides and follow label directions.

\section{Fertilization}

Phosphatic clays have a high soil $\mathrm{pH}(>7.0)$ and high $\mathrm{P}, \mathrm{K}, \mathrm{Ca}$, and $\mathrm{Mg}$. levels. Only nitrogen is required for fertilization. Nitrogen recommendations for perennial grasses and sorghum is 160 to $200 \mathrm{lbs}$ of $\mathrm{N}$ per acre per year. Leucaena, being a legume, requires no additional nitrogen. Nitrogen may be supplied in an organic or inorganic form or a combination of both. Common forms of inorganic nitrogen include ammonium nitrate $(32 \% \mathrm{~N})$, ammonium sulfate $(21 \% \mathrm{~N})$, or urea $(45 \% \mathrm{~N})$. Organic $\mathrm{N}$ sources include compost, animal manures, and sludge from municipal waste water treatment. Urea should only be used if it is soil incorporated or 
banded to a depth of $>3$ inches to prevent volatilization and loss of nitrogen to the atmosphere.

Since neither phosphorus nor potassium is needed on phosphatic clay soil, only nitrogen will be discussed. Due to the close proximity of the phosphate mining area to a number of metropolitan areas, there is an opportunity to use municipal sludge as an economical source of nitrogen. Application of municipal sludge is regulated by the Florida Department of Environmental Protection (DEP) (Chapter 17-640 F.A.C.).

Municipal sludge comes in three forms: liquid, cake, and dried. Liquid sludge has only 1 to $3 \%$ dry matter, cake sludge has a dry matter content of 10 to $20 \%$ and dried sludge has 90 to $95 \%$ dry matter. Nitrogen content mostly falls in the range of $3 \%$ to $8 \%$ on a dry weight basis. Sludge and compost is usually hauled to the field at no cost to the grower. Typically, the grower either spreads the material himself or pays the hauler for land-spreading.

A number of factors must be considered when calculating the amount of sludge to apply per acre to supply the desired amount of nitrogen. These factors include the amount of moisture in sludge, percent of nitrogen present, amount of nitrogen available to the crop in the current application plus carryover from previous applications, if any (Figure 1). Although the example in Figure 1 uses cake sludge, the same procedures apply to other organic materials.

Earlier studies on phosphatic clay soils have shown that municipal sludge is a dependable source of nitrogen for growing crops. When surface applied, about $45 \%$ of the nitrogen in municipal sludge is available to the plant in the first year. The remaining $55 \%$ of the nitrogen carries over to the second and third year at about $50 \%$ of the remaining amount each year.

\section{Harvest Management}

Harvesting perennial grasses and sorghum with large capacity silage equipment will likely be the most labor efficient way of handling these crops. A stubble height of 2 to 3 inches should be left so the crop will ratoon (grow the next crop) properly.

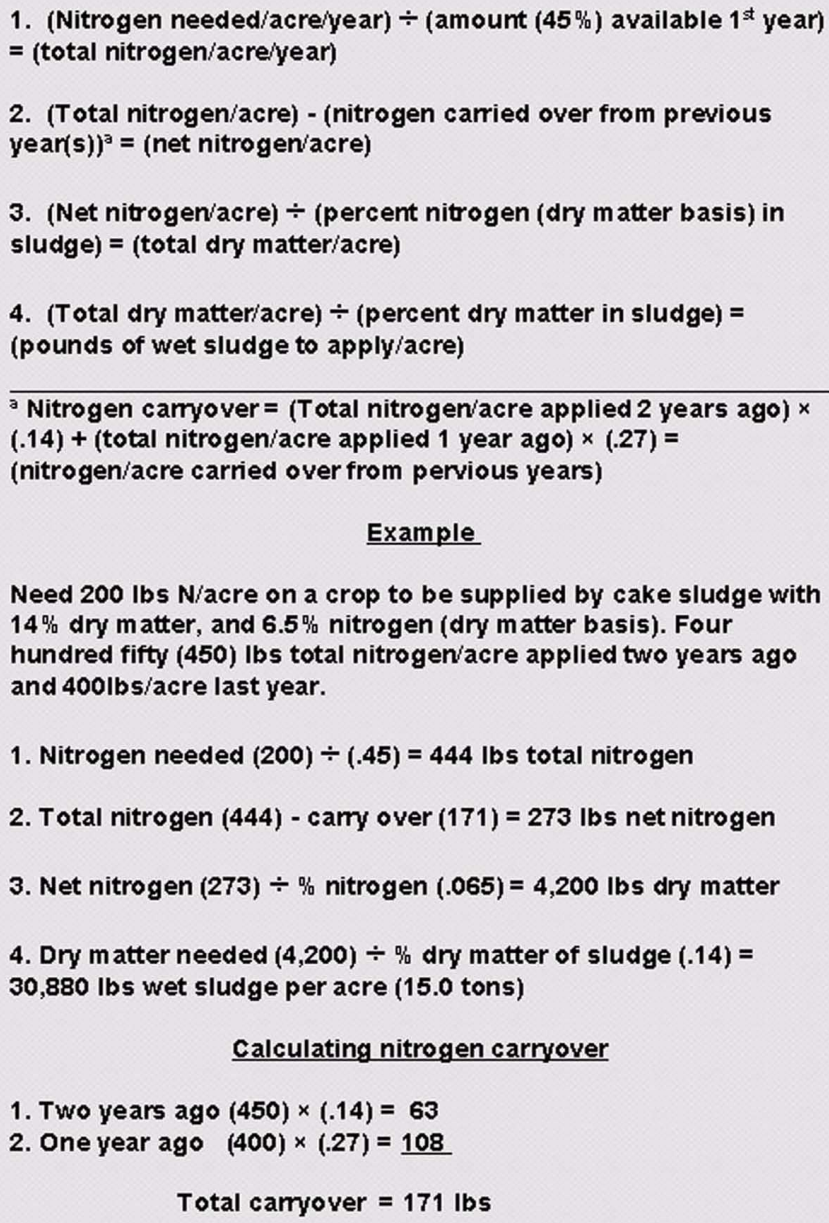

Need 200 Ibs N/acre on a crop to be supplied by cake sludge with $14 \%$ dry $m$ atter, and $6.5 \%$ nitrogen (dry matter basis). Four hundred fifty (450) lbs total nitrogen/acre applied two years ago and $400 \mathrm{lbs} /$ acre last year.

1. Nitrogen needed $(200) \div(.45)=444$ lbs total nitrogen

2. Total nitrogen (444) - carry over $(171)=273$ lbs net nitrogen

3. Net nitrogen $(273) \div \%$ nitrogen $(.065)=4,200$ lbs dry matter

4. Dry $m$ atter needed $(4,200) \div \%$ dry matter of sludge $(.14)=$ 30,880 lbs wet sludge per acre ( 15.0 tons)

Calculating nitrogen carnyover

1. Two years ago $(450) \times(.14)=63$

2. One year ago $(400) \times(.27)=\underline{108}$

Total caryover $=171 \mathrm{lbs}$

Figure 1.

Leucaena, being a woody plant, will require hand harvesting and chipping. It may also be possible to adapt specialized equipment from the forest industry for the harvesting and handling of leucaena for energy production. High capacity forage harvesting equipment fitted with a special wood-cutter head is also a possibility on large acreages.

\section{Energy Requirements}

Energy is an important economic and environmental component in the production of agricultural products, especially the manufacture and transport of fertilizer materials. Use of readily available waste products as a source of plant nutrients can have both an environmental and economic benefit. The phosphate mining area in central Florida is located close to several metropolitan areas and the disposal of municipal sludge presents a problem.

A comparison was made between the amount of energy required to supply $200 \mathrm{lbs}$ of actual nitrogen 
from either ammonium nitrate $(34 \% \mathrm{~N})$ or from municipal sludge. Assumptions were: Sludge contains $6.5 \%$ nitrogen on a dry matter basis and is transported 40 miles (one way) from the waste water treatment plant to the field. The quantity of material hauled per load is enough to supply $\mathrm{N}$ to one acre of land. Ammonium nitrate is hauled 15 miles from the plant to the field and enough material is hauled to supply $\mathrm{N}$ to 75 acres of land. The hauling distances for the two materials and the quantity hauled is considered typical for this area. All cultural practices other than nitrogen source and method of land spreading are the same.

Energy required for using ammonium nitrate was $81 \%$ greater than that needed for sludge (Table 3 ). The greatest energy requirement when using sludge was fuel for hauling sludge from the water treatment plant to the field. The greatest energy requirement for ammonium nitrate was for the manufacture of the material itself.

\section{Establishment Costs}

Once established, a stand of perennial biomass/energy crop is expected to remain productive for a period of 6 years or more.

Establishment costs are averaged over the expected life of the stand. Annual maintenance, harvest, and handling costs are added to the prorated establishment costs. Because of limited space in this paper, the discussion here focuses on estimated costs for establishing an acre of sugarcane or elephantgrass (Table 4).

A computerized budget generator developed by the Food and Resource Economics Department at the University of Florida (AGSYS Budget Generator) was used to estimate costs for this analysis. Field operations for seed bed preparation included plowing with a moldboard plow, tilling once with a co-rotational power tiller, followed by a disc harrow and then two passes with a spring-tooth harrow. Planting operations included plowing furrows with a two-row middle buster then planting seed cane by hand. Furrows were covered with a co-rotation power tiller and the field was then sprayed with a pre-emergent herbicide. No irrigation was used since it was assumed the crops were planted in late November and would develop slowly in cool soil, providing ample time for rain to adequately supply water.

Municipal sludge costs slightly less than ammonium nitrate as a nitrogen source. It was assumed that the municipal sludge was transported to the field at no cost to the grower and that the grower was responsible for spreading. Should the grower be required to pay for transporting the sludge, the economic outcome would likely be in favor of the ammonium nitrate.

\section{Conclusion}

Markets for biomass crops have been slow to develop. The concept of co-firing biomass in existing power plants continues to show promise. Electric utilities are interested in co-firing biomass as a way to meet the renewable energy mandate, should it become law. In addition, there are air quality benefits from biomass fuels. Since biomass fuels are low in sulfur and nitrogen, $\mathrm{SO}_{\mathrm{x}}$ which causes acid rain and $\mathrm{NO}_{\mathrm{x}}$ which contributes to smog is lower in smokestack emissions when biomass fuels are burned with coal. At least one project developer, The Common Purpose Institute (http://www.serve.com/commonpurpose/), is actively working to develop a market for biomass fuel in central Florida.

Presently, ethanol is in demand for use with gasoline to make gasohol; there is also a market for both beverage and industrial ethanol in central Florida. Two ethanol plants located near Bartow are presently idle. These plants use conventional technology to produce ethanol. With conventional technology, only the sugars/starches in juice pressed from sugarcane can be fermented into ethanol. A crop yielding 20 tons of dry weight (80 tons of fresh material) per acre will yield about 800 gallons of ethanol per acre. Technology is being developed that will convert cellulosic materials as well as sugars/starches to ethanol. With this new technology, 20 tons ( 80 tons fresh weight) of material may yield as much as 2,340 gallons of ethanol per acre (Asghari, et al.,1995; Stricker, et al., 1995). 


\section{References}

Anderson, D. L. 1991. Fertilizer and Liming Sources Used in the U.S. Agricultural

Experiment Station, Institute of Food and Agricultural Sciences, University of Florida. Circular S-383.

Asghari, A. and J. Gerber. 1995. Conversion of Cellulosic Biomass to Ethanol. In Economic Development Through Biomass Systems Integration in Central Florida. pgs. 74-83. Golden CO: National Renewable Energy Laboratory. Work performed by Univ. of Fla. Center for Biomass Programs, Gainesville, FL 32611 .

Bennett, A.C., B.J. Brecke, J.A. Dusky, G.E. MacDonald, J.J. Mullahey, J.T. Ducar, V.V. Vandiver, E.B. Whitty (J.T. Ducar, Ed.). 2002 Weed Management for Agronomic Crops and Non-Crop Areas in Florida. Univ. of Fla. Coop. Ext. Ser. SS-AGR-20. Jan. 2002.

Cook, J. and J. Beyea. 1996. An Analysis of the Environmental Impacts of Energy Crops in the USA: Methodologies, Conclusions and Recommendations. Environmental Impact of Biomass for Energy. Nov. 4-5, 1996. Noordwijkerhout, the Netherlands.

(

http://www.panix.com/ jimcook/data/ecworkshop.html)

Deboys, R.S. 1995. Second field trials of short rotation coppice harvesters. Forestry Commission. The Forest Authority. Technical Development Branch. AE village, Dumfries UK. Report 1/95, pp. 52.

Hanlon, E. A., H. W. Kananen and E. C. French. 1991. Guidelines for Reclaiming Phosphatic Clay Settling Areas for Intensive Agriculture. Polk County Mined Lands Agricultural Research/Demonstration Project. University of Florida SS-MLR-01. Feb. 1994.

Jerez, R. A., E. A. Hanlon, and G. J. Hochmuth. 1989. Sludge-amended phosphatic clays for sweet corn production. Agron. Abstracts. pp. 243.
Mislevy, P., W. G. Blue, and C. E. Roessler. 1989. Productivity of Clay Tailings from Phosphate Mining: I. Biomass Crops. J. Environ. Qual. 18:95-100.

Planet Power. (n.d.). Quick Facts on Energy Crops and Why We Need to Use Them.

Retrieved August 7, 2003, from

http://www.treepower.org/quickfacts.html.

Prine, G. M., P. Mislevy, R. L. Stanley, Jr., and D. I. Bransby. 1991. Field Production of Energycane, Elephantgrass, and Sorghum in Southeastern United States. In Proceedings, Conference on Energy from Biomass and Waste XV. March 25-29. Hyatt Regency, Washington, DC. Paper 24.

Prine, G. M., J. A. Stricker, and D. B. Shibles. 1991. Energy Crops Have Potential on Phosphatic Settling Ponds Clays. [abstract] In Florida Scientist. 55th Annual Meeting Florida Academy of Sciences. May 9-11, 1991 St. Leo College, St. Leo, FL. Vol. 54 p. 2.

Prine G. M., J. A. Stricker, and D. B. Shibles. Growing Energy Crops on Phosphatic Settling Pond Clay in Polk County. [Abstract] 54th Annual Meeting, Florida Academy of Sciences. Daytona Beach, FL. March 24, 1990. Vol. 53, p. 92.

Prine, G. M. and P. Mislevy. 1983. Grass and Herbaceous Plants for Biomass. In Proceedings Soil and Crop Science Society of Florida. Vol. 42. pp. 8-12.

Rahmani, M., A.W. Hodges, J.A. Stricker, and C.F. Kiker.2003. Will investing in renewable energy pay off?: A case study in Florida. In Proceedings of The Third Annual Conference, 2003 Hawaii International Conference on Business. Honolulu, HI, June 18 - 21 (CD ROM ISSN \#1539-722X).

Segrest, S. A., D. L. Rockwood, J. A. Stricker, A. E. S. Green, W. H. Smith, and D. R. Carter. 1998. Biomass Co-Firing with Coal at Lakeland, Florida, Utilities. Proc. BioEnergy98: Expanding BioEnergy Partnerships. Madison, WI. October 4-8, 1998. pgs. 315-325 
Solar Energy Research Institute, Simultaneous

Saccharification and Fermentation," Science \&

Technology Brief, Biofuels/15, 1990.

Solar Energy Research Institute, Xylose

Fermentation, Science and Technology Brief,

Biofuels/14, 1989

Spinelli, R., and P. Kofman. 1996. A Review of

Short Rotation Forestry Harvesting in Europe. In

Proceedings, First Conference of the Short

Rotation Woody Crops Operations Working

Group, Paducah, KY. September 23-25. pp.

99-110.

Stricker, J.A. 2000. High Value Crop Potential of Reclaimed Phosphatic Clay Soil. In W.L.

Daniels, and S.G. Richardson (eds.) Proceedings, 2000 Annual Meeting of the American Society

for Surface Mining and Reclamation, Tampa, FL, June 11-15, 2000. Amer. Soc. Surf. Mining

Rec., 3134 Montavesta Rd., Lexington, KY. pp.

644-654

Stricker, J.A., S.A. Segrest, D.L. Rockwood, and G.M. Prine. 1999. Model Fuel Contract -

Co-Firing Biomass with Coal. Soil and Crop Sci.

Soc. Florida Proc. 59:98-102 (2000)

Stricker, J.A., M. Rahmani, A.W. Hodges, J.W. Mishoe, G.M. Prine, D.L. Rockwood, and A.

Vincent. 1995. Economic Development Through Biomass Systems Integration in Central Florida. In Proceedings of Second Biomass Conference of the Americas: Energy, Environment, Agriculture, and Industry, NREL/CP-200-8098, Aug. 21-24, 1995, Portland, OR. National

Renewable Energy Laboratory, Golden, CO. pp 1608-1617.

Stricker, J. A. 1986. Mined Soil Characteristics. In Florida's Natural Resources. Center for Natural Resources, University of Florida, Institute of Food and Agricultural Sciences. Vol. 1, No. 2 Fall 1986.

Woodard, K. R., and G. M. Prine. 1991. Forage Yield and Nutritive Value of Elephantgrass as Affected by Harvest Frequency and Genotype. Agron. J. 83:541-546. 
Table 1. Energy crops, dry matter yield, and yield trend.

\begin{tabular}{|c|c|c|c|}
\hline Crop & Accession & Ton/acre & Yield trend ${ }^{a}$ \\
\hline Elephantgrass ${ }^{b}$ & PI 300086 & 21 & increase \\
\hline Elephantgrass $^{1}$ & N51 & 20 & decrease \\
\hline Energycane $^{1}$ & L79-1002 & 19 & decrease \\
\hline Energycane $^{1}$ & US72-1153 & 22 & increase \\
\hline Energycane $^{1}$ & $1 \mathrm{~K}-7647$ & 22 & (3 year data) \\
\hline Sugarcane $^{1}$ & US78-1009 & 22 & decrease \\
\hline Sugarcane $^{1}$ & US56-9 & 23 & variable \\
\hline Sugarcane $^{1}$ & CP72-1210 & 24 & variable \\
\hline Erianthus $^{2}$ & IK 76-63 & 60 & increase \\
\hline Sweet Sorghum ${ }^{2}$ & USDA M81E & 13 & (2 year data) \\
\hline Forage Sorghum ${ }^{2}$ & Pioneer 931 & 17 & (2 year data) \\
\hline Leucaena $^{2}$ & & 26 & increase \\
\hline \multicolumn{4}{|c|}{${ }^{\mathrm{a}}$ Trend of yields over 4 year period when data available. } \\
\hline \multicolumn{4}{|c|}{${ }^{\mathrm{b}}$ Average of yields from two studies. } \\
\hline \multicolumn{4}{|c|}{${ }^{1}$ Source: Prine, et al., 1990} \\
\hline \multicolumn{4}{|c|}{${ }^{2}$ Source: Mislevy, et al., 1989} \\
\hline
\end{tabular}

Table 2. Planting periods for biomass crops.

\begin{tabular}{||l|c|c|c|c|c|c|c|c|c|c|c|c||}
\hline \hline & \multicolumn{10}{|c||}{ Months } \\
\hline Crops & $\mathbf{1}$ & $\mathbf{2}$ & $\mathbf{3}$ & $\mathbf{4}$ & $\mathbf{5}$ & $\mathbf{6}$ & $\mathbf{7}$ & $\mathbf{8}$ & $\mathbf{9}$ & $\mathbf{1 0}$ & $\mathbf{1 1}$ & $\mathbf{1 2}$ \\
\hline Perrenial grasses & $\mathrm{X}$ & & & & & & & $\mathrm{X}$ & $\mathrm{X}$ & & $\mathrm{X}$ & $\mathrm{X}$ \\
\hline Sorghum & & & $\mathrm{X}$ & $\mathrm{X}$ & $\mathrm{X}$ & $\mathrm{X}$ & $\mathrm{X}$ & $\mathrm{X}$ & & & & \\
\hline Leucaena & & & & $\mathrm{X}$ & $\mathrm{X}$ & $\mathrm{X}$ & $\mathrm{X}$ & & & & & \\
\hline \hline
\end{tabular}

Table 3. Energy required by supplying nitrogen with municipal sludge vs. ammonium nitrate.

\begin{tabular}{||l|c|c||}
\hline \hline & \multicolumn{2}{|c||}{$\begin{array}{c}\text { Energy Used to Supply Nitrogen from } \\
\text { Different Sources, GDFE* }\end{array}$} \\
\hline Activities/ Inputs & Sludge & $\begin{array}{c}\text { Ammonium } \\
\text { Nitrate }\end{array}$ \\
\hline $\begin{array}{l}\text { Soil Prepare and } \\
\text { plant }\end{array}$ & 9.9 & 9.9 \\
\hline Transport fertilizer & 20.0 & 0.1 \\
\hline Spread fertilizer & 3.3 & 0.2 \\
\hline Ammonium nitrate & -- & 51.7 \\
\hline Atrazine & 2.2 & 2.2 \\
\hline Total DFE & 35.4 & 64.1 \\
\hline $\begin{array}{l}\text { *Gallons of Diesel Fuel Equivalent (GDFE): energy inputs } \\
\text { equal to the energy in gallons of diesel fuel listed. }\end{array}$ \\
\hline \hline
\end{tabular}


Table 4. Estimated cost for establishing an acre of sugarcane or elephantgrass with sludge vs. ammonium nitrate.

\begin{tabular}{||l|c|c|l||}
\hline \hline \multirow{2}{*}{ Item } & \multicolumn{2}{|c||}{ Nitrogen source } & \multicolumn{1}{c||}{ Quantity: } \\
\hline Atrazine & Sludge & Am. nitrate & \\
\hline Ammonium nitrate 34\% & 24.00 & 24.00 & $8 \mathrm{lb} . /$ acre \\
\hline Municipal sludge (wet) & -- & 43.20 & $588 \mathrm{lb}$./acre \\
\hline Seed cane & -- & -- & $30,000 \mathrm{lb} . / \mathrm{acre}$ \\
\hline Machinery costs (sludge) & 200.00 & 200.00 & $5 \mathrm{ton} /$ acre \\
\hline Machinery costs (Am. Nit.) & 32.37 & -- & $3.81 \mathrm{hr} /$ acre \\
\hline Machine labor (sludge) & -- & 24.10 & $3.22 \mathrm{hr} /$ acre \\
\hline Machine labor (Am. Nit.) & 20.93 & -- & $3.81 \mathrm{hr} /$ acre \\
\hline Hand labor - planting & -- & 17.73 & $3.22 \mathrm{hr} /$ acre \\
\hline Interest & 116.20 & 116.20 & $20 \mathrm{hr} / \mathrm{acre}$ \\
\hline Total variable costs & 94.44 & 102.03 & $8 \%$ for 3 yrs \\
\hline Machinery (sludge) & 487.94 & 527.26 & -- \\
\hline Machinery (Am. Nit.) & 29.19 & -- & $3.81 \mathrm{hr} /$ acre \\
\hline Supervision @ 22\% of labor cost & -- & 23.87 & $3.22 \mathrm{hr} /$ acre \\
\hline Overhead @ 5\% of Var. cost & 30.16 & 29.46 & -- \\
\hline Total fixed costs & 24.39 & 26.36 & -- \\
\hline Total establishment cost/acre & 83.74 & 79.69 & -- \\
\hline Average annual cost over 6 years & 571.68 & 606.95 & -- \\
\hline \hline
\end{tabular}

